\title{
Profile of the orthodontist practicing in the state of São Paulo - Part 1
}

\author{
Fabio Brandalise Rampon', Celestino Nóbrega ${ }^{2}$, José Luiz Gonçalves Bretos ${ }^{3}$, Franco Arsati ${ }^{4}$, Sérgio Jakob ${ }^{5}$, Maria Cristina Jimenez-Pellegrin ${ }^{6}$
}

\begin{abstract}
Introduction: Orthodontics is no different from other sciences to the extent that it is afield in constant evolution and development. Nowadays, given the availability of a wide range of materials and biomechanical resources, as well as the development of new diagnostic capabilities, new methods to manage orthodontic treatment have emerged. Furthermore, due to the proliferation of postgraduate programs, it is increasingly important to gain insight into the profile of these specialists and the resources they use. Objective: Examine the profile of orthodontists practicing in the State of São Paulo. The questions were prepared to evaluate different aspects of orthodontic practice. Methods: A questionnaire was sent to 2.414 specialists in Orthodontics and Dentofacial Orthopedics registered with the Regional Board of Dentistry of São Paulo State (CRO-SP). To assess the association between qualitative variables, the Chi-square association test was employed at $5 \%$ significance level. Results: Five hundred ninety-three (24.65\%) questionnaires were completed and returned. The sample profile consisted of males (54.3\%), aged between 41 and 50 (40.5\%), who had been registered with the São Paulo Regional Board of Dentistry (CRO-SP) for 6 to 10 years (29.3\%). The three most widely mentioned cephalometric analyses were standard USP (71.5\%), McNamara (59.2\%) and Ricketts (52.8\%). Conclusions: Based on a statistical analysis of the data one can conclude that the Straight-Wire technique was used most often (74.5\%), and this technique is associated with orthodontists who have been specialists for less than 10 years. Most people surveyed (52.4\%) routinely make use of functional orthopedic resources in their daily practice.
\end{abstract}

Keywords: Dental research. Distribution by age and sex. Techniques.

Introdução: a Ortodontia, como toda ciência, é um campo em permanente evolução e desenvolvimento. No panorama atual, devido à oferta de diversos tipos de materiais e das opções biomecânicas existentes, além do desenvolvimento de novos recursos de diagnóstico, surgiram novas possibilidades de se abordar o tratamento ortodôntico. Em adição, com o aumento dos cursos de pós-graduação, torna-se importante conhecer o perfil do especialista e os recursos de sua preferência. Objetivo: analisar o perfil do ortodontista que atua no estado de São Paulo, por meio de questões elaboradas com o objetivo de avaliar aspectos relacionados à prática ortodôntica. Métodos: foi enviado um questionário a 2.414 especialistas em Ortodontia e Ortopedia Facial inscritos no Conselho Regional de Odontologia do estado de São Paulo. Para avaliar a associação entre as variáveis qualitativas, foi utilizado o teste de associação Qui-quadrado, ao nível de significância de $5 \%$. Resultados: foram devolvidos 593 (24,65\%) questionários preenchidos. O perfil da amostra foi sexo masculino (54,3\%), faixa etária entre 41 e 50 anos (40,5\%) e com tempo de inscrição no CRO-SP de 6 a 10 anos (29,3\%). As três análises cefalométricas mais citadas foram o padrão USP (71,5\%), McNamara (59,2\%) e Ricketts (52,8\%). Conclusões: com base na análise estatística dos dados, pode-se concluir que a técnica Straight-Wire foi a mais empregada (74,5\%), a qual está associada a ortodontistas com menos de 10 anos de especialidade. A maioria da população pesquisada (52,4\%) utiliza, de forma rotineira, recursos ortopédicos funcionais no seu dia a dia.

Palavras-chave: Pesquisa em Odontologia. Distribuição por idade e sexo. Técnicas.

${ }^{1}$ MSc in Dentistry, São Leopoldo Mandic School of Dentistry.

${ }^{2}$ Specialist in Orthodontics, ABO. MSc in Oral Radiology UNICASTELO.

${ }^{3} \mathrm{MSc}$ in Orthodontics, UNICASTELO. PhD in Sciences, UNIFESP.

${ }^{4} \mathrm{MSc}$ and $\mathrm{PhD}$ in Dentistry, Unicamp.

${ }^{5} \mathrm{MSc}$ in Orthodontics, UNICASTELO. PhD in Dentistry, São Leopoldo Mandic

School of Dentistry.

${ }^{6}$ Professor, São Leopoldo Mandic School of Dentistry. MSc in Orthodontics,São Leopoldo Mandic School of Dentistry. Specialist in Orthodontics, UNICASTELO. $\mathrm{PhD}$ in Sciences, USP.

\footnotetext{
How to cite this article: Rampon FB, Nóbrega C, Bretos JLG, Arsati F, Jacob S, Jimenez-Pellegrin MC. Profile of the orthodontist practicing in the state of São Paulo - Part 1. Dental Press J Orthod. 2012 Nov-Dec;17(6):22.el-6.

Submitted: June 17, 2009 - Revised and accepted: June 30, 2010

» The author reports no commercial, proprietary or financial interest in the products or companies described in this article.

Contact address: Cristina Jimenez-Pellegrin

Rua José Rocha Junqueira, 13 - Ponte Preta - Campinas/SP - Brazil

CEP: 13.045-610 - E-mail: crisjp@globo.com
} 


\section{INTRODUCTION}

Orthodontics is the oldest dental specialty, as it was the first to organize and establish itself in fact and in law. Increasing interest in this profession leads many to search for information about it in all parts of the world so that knowledge about its origins, precursors and pioneers is widespread. Such knowledge is essential to fully understand dentistry's current evolutionary stage. ${ }^{17}$

Currently, clinicians are faced with different philosophies or approaches to treatment planning and a variety of biomechanical resources. Nevertheless, the supply of different bracket designs with different prescriptions and orthodontic wires featuring different properties makes it necessary to choose the resource most suitable to each case.

Every day new research and new technologies are offered to professionals with the purpose of facilitating their practice and providing comfort to patients. However, knowledge and mastery of these resources are essential.

In parallel, there has been a substantial increase in the number of postgraduate courses that deliver into the market a younger generation of orthodontists whose characteristics are different from those of the older generation.

In this context, it becomes important to shed light on the professional profile of orthodontists who practice in São Paulo, the major Brazilian state, accounting for $59.4 \%$ of nationwide dental research. ${ }^{4}$ It is also apropos to learn about the techniques and resources employed by these health care providers to meet the expectations of their patients.

\section{METHODS}

To conduct this research the Regional Board of Dentistry of São Paulo was requested to provide a list of addresses of all specialists in Orthodontics and Facial Orthopedics registered by May 2007, comprising a total of 2,414 professionals. The questionnaire included a prepaid reply envelope and had 20 objective questions, eight of which gave respondents the opportunity to check more than one alternative. In addition, 10 questions allowed professionals to add a written response with a descriptive text of their own. Each participant was duly informed about the nature of the research and assured full confidentiality of all information provided, to be used exclusively in the research pursuant to a consent form, which was duly signed by all. A prepaid reply service agreement was signed with the Post and Telegraph Company. This service exempted respondents from any expenses. Professionals received the questionnaire at their registered address and all they had to do was answer the questionnaire, fold it and glue it as indicated and mail it from any post office in Brazil. The mail was posted so that it did not reach its destination at the end of the week, but preferably earlier in the week, when prepaid reply letters are more likely to be returned. ${ }^{11}$ Based on the responses to the questionnaires an attempt was made to fully describe and interrelate the information in order to extract as much data as would be required to reach conclusions consistent with the purpose of this study. Computer software, i.e., Microsoft Excel ${ }^{\infty}$ and Microsoft Windows XP's graphical wizard, were used for data entry. Questionnaire responses were analyzed through charts and tables and classified according to either absolute (n) or relative frequency (\%). To assess the association between qualitative variables, the Chi-square association test was applied. Where the chi-square test was significant, adjusted residual analysis was used as a complement. Statistical analysis was performed using software SPSS $^{\circledast}$ version 13.0.

\section{RESULTS}

Sample size was set to the number of completed questionnaires received by the researchers. Out of a total of 2414 prepaid reply letters sent to the target population, $593(24.56 \%)$ were returned to the sender with completed questionnaires, 64 (2.65\%) were returned to the sender by return mail due to insufficient, unknown or change of address, and 1757 (72.78\%) were not returned.

\section{Professional profile}

The profile of the selected sample comprised: males (54.3\%), aged between 41 and 50 (40.5\%), who had been registered with the São Paulo Regional Board of Dentistry (CRO-SP) for 6 to 10 years (29.3\%).

Concerning the time of registration as orthodontic specialists with the Regional Board of Dentistry 
of São Paulo, out of 593 respondents, $8.1 \%$ had been registered for over 25 years, $8.3 \%$ from 21 to 25 years, $9.1 \%$ between 16 and 20 years, $16.2 \%$ from 11 to 15 years, $29.3 \%$ between 6 to 10 years and $26.8 \%$ between 1 and 5 years ( $2.2 \%$ of the sample did not answer this question).

The relationship between respondent gender and age is detailed in Table 1 where, using $\chi^{2}$ test, complemented by adjusted residual analysis at a 5\% significance, it was found that men's age group consisted of individuals over 50 years of age, while the women's age group remained below 40 years.

\section{Analyses}

The orthodontists were inquired about which analyses they usually request (Table 2 ).

\section{Orthodontic techniques}

The first part of the question regarded the choice of orthodontic technique, if it was made according to the type of malocclusion, and it became clear that there was no prevailing opinion (Fig 1) and, when the response was affirmative, the second part requested respondents to describe the clinical situation in which this choice was made (Table 3).
Table 1 - Distribution of orthodontists according to gender and age.

\begin{tabular}{|c|c|c|c|c|c|c|}
\hline \multirow{3}{*}{$\begin{array}{l}\text { Age } \\
\text { Group }\end{array}$} & \multicolumn{4}{|c|}{ Gender } & \multirow{2}{*}{\multicolumn{2}{|c|}{ Total }} \\
\hline & \multicolumn{2}{|c|}{ Male } & \multicolumn{2}{|c|}{ Female } & & \\
\hline & $n$ & $\%$ & $n$ & $\%$ & $n$ & $\%$ \\
\hline Up to 40 & 112 & 35.1 & 117 & $44.2^{\star}$ & 229 & 39.2 \\
\hline 41 to 50 & 121 & 37.9 & 117 & 44.2 & 238 & 40.8 \\
\hline Over 50 & 86 & $27.0^{\star}$ & 31 & 11.7 & 117 & 20.0 \\
\hline Total & 319 & 100 & 265 & 100 & 584 & 100 \\
\hline
\end{tabular}

$\chi^{2}=21,22 ; p<0,001 .{ }^{*}$ Adjusted Residual Analysis: $p<0.05$.

Table 2 - Distribution of the major analyses requested by orthodontists.

\begin{tabular}{lcc}
\hline & $\mathbf{n}$ & \% \\
\hline USP & 424 & 71.5 \\
McNamara & 351 & 59.2 \\
Ricketts & 313 & 52.8 \\
Jarabak & 177 & 29.8 \\
Tweed & 67 & 11.3 \\
Steiner & 64 & 10.8 \\
Wits & 40 & 6.7 \\
Bimler & 37 & 6.2 \\
Unicamp & 15 & 2.5 \\
Schwars & 13 & 2.2 \\
Trevisi & 10 & 1.7 \\
Profis & 8 & 1.3 \\
Petrovic & 6 & 1.0 \\
Does not request & 5 & 0.8 \\
Other & 40 & 6.4 \\
Total & $\mathbf{5 9 3}$ & - \\
\hline
\end{tabular}

Table 3 - Distribution of orthodontists according to clinical situations in which a given orthodontic technique was preferred.

\begin{tabular}{lcc} 
& $\mathbf{n}$ & \% \\
\hline Class III & 38 & 13.4 \\
Class II & 26 & 9.2 \\
Age & 23 & 8.1 \\
Facial pattern & 23 & 8.1 \\
Anchorage control & 16 & 5.6 \\
High complexity & 15 & 5.3 \\
Brackets tipping & 5 & 1.8 \\
Other & 53 & 18.7 \\
Total & $\mathbf{2 8 4}$ & - \\
\hline
\end{tabular}

Multiple response question.
Figure 1 - Distribution of orthodontists regarding the choice or not of orthodontic technique according to the type of malocclusion. 


\section{Multiple response questions}

Among the most commonly used orthodontic techniques (Table 4) it was noted that - by means of the $\chi^{2}$ Test, complemented by the adjusted residual analysis at a 5\% significance level, the use of the Straight-Wire technique is associated with specialists with less than 10 years practice, while its non-use is associated with a period of over 15 years; the edgewise technique is associated with specialists with over 15 years and its nonuse is linked to a range between 6 and 10 years; Ricketts' bioprogressive technique is associated with more than 15 years of practice (Table 5 ).

\section{Functional orthopedic resources}

One of the questions inquired about the percentage with which functional orthopedic resources were employed (Fig 2).

Table 4 - Distribution of orthodontists according to the technique most often used in orthodontic practice.

\begin{tabular}{|ccc|}
\hline & $\mathbf{n}$ & $\%$ \\
\hline Straight-Wire & 442 & 74.5 \\
Edgewise & 112 & 18.9 \\
Ricketts' Bioprogressive & 101 & 17.0 \\
Segmented arch & 92 & 15.5 \\
MD3 & 26 & 4.4 \\
MBT & 15 & 2.5 \\
Tweed-Merrifield & 10 & 1.7 \\
Begg & 4 & 0.7 \\
Other & 24 & 4.1 \\
Total & $\mathbf{5 9 3}$ & - \\
\hline
\end{tabular}

Multiple response question.

\section{DISCUSSION}

Knowledge of the professional profile is of paramount importance in evaluating many factors related to training, continuing education, preferences and needs of those who pursue a specific activity.

This study sought to glean information that might contribute to shedding light on the features of orthodontists with practices in São Paulo State, Brazil and, to this end, a survey was conducted through questionnaires mailed with prepaid reply envelopes. Out of a total of 2,414 questionnaires $24.56 \%$ returned to the sender, similarly to the studies by Pissetti and Feres ${ }^{13}$ who received $27.24 \%$ of the questionnaires back, Souza et al, ${ }^{16}$ with $22.92 \%$, and Soares et al, ${ }^{15}$ with $27.43 \%$. In other studies, the rate of return of mail was much lower, as that of Queiroz Jr and Feres ${ }^{14}(15.65 \%)$; Gottlieb et $\mathrm{al}^{5}$ (14\%), Gottlieb et $\mathrm{al}^{6}$ (11.2\%); Keim et $\mathrm{al}^{7}$ (9\%).

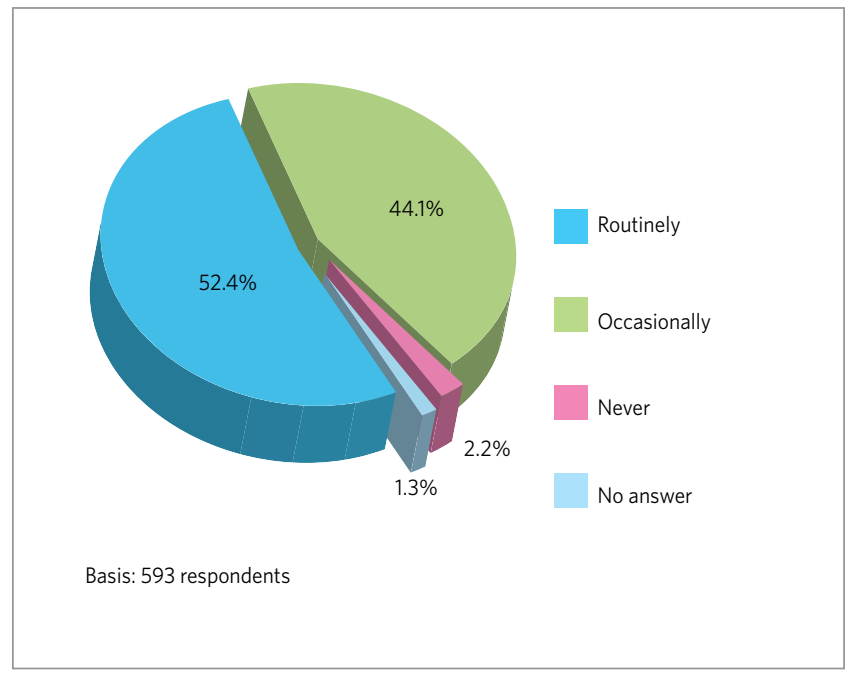

Figure 2 - Distribution of orthodontists according to the use of functional orthopedic resources.

Table 5 - Relationship between time length of orthodontic practice and technique used.

\begin{tabular}{|c|c|c|c|c|c|c|c|c|c|c|c|c|}
\hline \multirow{4}{*}{$\begin{array}{c}\text { Time } \\
\text { length of } \\
\text { O. P. } \\
\text { (years) }\end{array}$} & \multicolumn{12}{|c|}{ Technique } \\
\hline & \multicolumn{4}{|c|}{ Straight-Wire } & \multicolumn{4}{|c|}{ Edgewise } & \multicolumn{4}{|c|}{ Ricketts's Bioprogressive } \\
\hline & \multicolumn{2}{|c|}{ does not request } & \multicolumn{2}{|c|}{ request } & \multicolumn{2}{|c|}{ does not request } & \multicolumn{2}{|c|}{ request } & \multicolumn{2}{|c|}{ does not request } & \multicolumn{2}{|c|}{ request } \\
\hline & $\mathbf{n}$ & $\%$ & n & $\%$ & $\mathbf{n}$ & $\%$ & $\mathbf{n}$ & $\%$ & $\mathbf{n}$ & $\%$ & n & $\%$ \\
\hline 1 to 5 & 29 & 19.5 & 130 & $30.2^{\star}$ & 133 & 28.4 & 26 & 23.2 & 141 & $29.3^{\star}$ & 18 & 18.2 \\
\hline 6 to 10 & 31 & 20.8 & 143 & $33.2^{*}$ & 153 & $32.7^{\star}$ & 21 & 18.8 & 140 & 29.1 & 34 & 34.3 \\
\hline 11 to 15 & 26 & 17.4 & 70 & 16.2 & 78 & 16.7 & 18 & 16.1 & 83 & 17.3 & 13 & 13.1 \\
\hline Over 15 & 63 & $42.3^{*}$ & 88 & 20.4 & 104 & 22.2 & 47 & $42.0^{\star}$ & 117 & 24.3 & 34 & $34.3^{*}$ \\
\hline Total & 149 & 100 & 431 & 100 & 468 & 100 & 112 & 100 & 481 & 100 & 99 & 100 \\
\hline$\chi^{2} ; p$ & \multicolumn{4}{|c|}{$\chi^{2}=30.7 ; p<0.001$} & \multicolumn{3}{|c|}{$\chi^{2}=20.30 ; p<0.001$} & & \multicolumn{3}{|c|}{$\chi^{2}=8.50 ; p=0.037$} & \\
\hline
\end{tabular}

${ }^{\star}$ Adjusted Residual Analysis: $p<0.05$. 
Fifty-four point three percent of the respondents were male and $44.7 \%$ female, similarly to the study by Smith et al, ${ }^{15}$ in which $55 \%$ of the orthodontists were male and $45 \%$ female, denoting gender balance. Although Murray ${ }^{1}$ reported a prevalence of women in England, he found that job aspirations are changing, that career interruption, part-time jobs, financial pressures, constant stress, job development and satisfaction, are not gender specific.

In this study, the age group that prevailed ranged from 41 to 50 years (40.5\%), consistent with the median age of Brazilian orthodontists, which was 42 years ${ }^{13,14}$ and 41 years, ${ }^{16}$ and with the median age of US orthodontists. ${ }^{5,6,7,12}$ On the other hand, Smith et $\mathrm{al}^{15}$ and Pantaleão ${ }^{12}$ found a prevalence of ages 31 to 40 years, with $55.05 \%$. Moreover, the female gender was associated with ages below 40 years and the male gender with ages above 50 years, corroborating Andrade. ${ }^{1}$

Results concerning the number of years orthodontists had been registered with the Regional Board of Dentistry (CRO-SP) disclosed a range of 6 to 10 years $(29.3 \%)$, followed by 1 to 5 years $(26.8 \%)$, similar to the values found by Pantaleão ${ }^{12}$ and by Soares et al, ${ }^{15}$ respectively, indicating that demand for specialization courses in orthodontics has increased in the last ten years.

Regarding preference for different cephalometric analyses, the São Paulo University (USP) standard predominated (71.5\%) as well as the study by Pantaleão. ${ }^{12}$ On the other hand, Steiner's was the most widely used analysis in other studies ${ }^{6,713,16}$ and ranked sixth (10.8\%) in this study.

When asked if they selected the orthodontic technique according to the type of malocclusion, 50.3\% gave a negative response while $47.9 \%$ reported that the orthodontic technique varied according to the clinical situation to be resolved. Given the descriptive nature of this question there was a wide range of replies, with particular emphasis on Class III (13.4\%) and Class II (9.2\%) cases, age and skeletal characteristics of the patient being treated (both $8.1 \%$ ). This response highlights the array of philosophies and biomechanical options currently available. ${ }^{2,8}$ Assuming, however, that any orthodontic technique should provide for the treatment of any type of malocclusion, this outcome seems inconsistent.
The development of new orthodontic materials is undoubtedly one of the most promising fields in the upcoming years. Currently, the edgewise technique is the foundation upon which the orthodontic specialty is grounded. Modifications and refinements to the original technique impart a new dynamics to clinical treatment, as represented by the groundbreaking Straight-Wire technique. ${ }^{8}$

Among the orthodontic techniques most commonly used by orthodontists in São Paulo State, the Straight-Wire technique $(74.5 \%)$ predominated, following the trend of US values found by Gottlieb et $\mathrm{al}^{5}(64.75 \%)$, Gottlieb et $\mathrm{al}^{6}(76.4 \%)$ and Keim et $\mathrm{al}^{7}$ (94.4\%), comprising all preadjusted technique prescriptions. This trend can also be seen in Brazil according to Souza et $\mathrm{al}^{16}(62.93 \%)$ and Pantaleão, ${ }^{12}$ who reported that over $90 \%$ of orthodontic professionals prefer this technique.

Statistical analysis showed an association between the use of the Straight-Wire technique and being a specialist for fewer than 10 years, as well as an association between non-use of this technique and being a specialist for longer than 15 years. In retrospect, percentage increases in the adoption of the Straight-Wire technique in Brazil have been confirmed by the findings of Queiroz Jr and Feres ${ }^{14}$ (32.62\%); Pissetti and Feres ${ }^{13}$ (41.14\%), Souza et $\mathrm{al}^{16}$ $(62.93 \%)$ and the present study (74.5\%). In the US, the total sum of preadjusted appliances of different prescriptions relative to the number of years in orthodontic practice has remained consistently and routinely above $90 \%$, such as in the age groups 1-5 years (98.9\%), 5 to 10 years $(93.4 \%)$ and $11-15$ years $(99.2 \%){ }^{7}$

Classical edgewise and Ricketts' bioprogressive techniques have proven to be more widely employed by more experienced professionals since these techniques were associated with specialists who had over 15 years experience, as corroborated by the study of Keim et al, ${ }^{7}$ which revealed that respondents with more than 26 years of orthodontic practice were the ones who more often applied these techniques.

One possible explanation for this finding might be the fact that less experienced orthodontists preferred not to use traditional techniques given their inability to make adjustments and bends to orthodontic wires, and therefore chose preadjusted appliances. It should 
be noted, however, that archwire individualization is an essential factor in properly finishing orthodontic treatment, even when straight wires are utilized, indicating that training in wire bending is paramount.

The routine use of functional orthopedic resources by $52.4 \%$, and occasional use by $44 \%$ of professionals showed an expressive overall acceptance, which proved higher than that found by preliminary studies. ${ }^{12,13,16}$

The joint work of orthodontists, who report their preferences and clinical needs side by side with companies, which develop, test and market new materials, seek to impart greater quality to orthodontic products.
Moreover, professional skill and scientific knowledge are the key to a successful treatment.

\section{CONCLUSION}

Field research outcomes led the authors to conclude that the Straight-Wire technique was the most widely used, and that this technique is associated with orthodontists who registered with the São Paulo Regional Board of Dentistry (SP-CRO) less than 10 years ago. Most professionals, when questioned, revealed that they use functional orthopedic resources routinely in their practice.

\section{REFERENCES}

1. Andrade M. A revolução silenciosa. Rev ABO Nac. 1999:7(2):198-201.

2. Brito Júnior VS, Ursi WJS. O aparelho pré-ajustado: sua evolução e suas prescrições. Rev Dental Press Ortod Ortop Facial. 2006;11(3):104-56.

3. Capelozza Filho L, Silva Filho OG, Ozawa TO, Cavassan AO. Individualização de braquetes na técnica straight-wire: revisão de conceitos e sugestão de indicações para uso. Rev Dental Press Ortod Ortop Facial. 1999;4(4):87-106.

4. Cavalcanti AL, Melo TRNB, Barroso KMA, Souza FEC, Maia AMA, Silva ALO. Perfil da pesquisa científica em Odontologia realizada no Brasil. Pesq Bras Odontoped Clin Integr. 2004;4(2):99-104.

5. Gottlieb EL, Nelson AH, Vogels DS. 1990 JCO study of orthodontic diagnosis and treatment procedures. 1. Results and trends. J Clin Orthod. 1991;25(3):145-56.

6. Gottlieb EL, Nelson AH, Vogels DS. 1996 JCO Study of orthodontic diagnosis and treatment procedures. Part 1. Results and trends. J Clin Orthod. 1996;30(11):615-29.

7. Keim RG, Gottlieb EL, Nelson AH, Vogels DS. 2002 JCO study of orthodontic diagnosis and treatment procedures. Part 1. Results and trends. J Clin Orthod. 2002;36(10):553-68.

8. Mazzieiro ET. Braquetes do sistema Straight-Wire: o que eles realmente significam? J Bras Ortodon Ortop Facial. 2005;10(58):449-59.

9. Mendonça S. Ortodontia nos tempos globalizados. São Paulo: Ed. Univ. Guarulhos; 2004.
10. Murray JJ. Better opportunities for women dentists: a review of the contribution of women dentists to the workforce. Br Dent J. 2002;192(4):191-6.

11. Oppenheim AM. Questionnaire design, interviewing and attitude measurement. $1^{\text {st }}$ ed. London: Pinter; 1993.

12. Pantaleão AM. Estudo da prática ortodôntica no Distrito Federal [dissertação]. Campinas (SP): São Leopoldo Mandic; 2007.

13. Pissette AP, Feres MAL. II Estudo sobre a prática ortodôntica no Brasil - 1995. Ortodontia. 1997;30(3):7-15

14. Queiroz Jr. G, Feres MAL. Estudo sobre a prática ortodôntica no Brasil. Ortodontia. 1994;27(3):67-77.

15. Soares ED, Carvalho AS, Barbosa JA. Relação comercial do ortodontista brasileiro com o seu paciente, natureza obrigacional dos serviços prestados e riscos do tratamento ortodôntico. Rev Dental Press Ortod Ortop Facial. 2007;12(1):94-101.

16. Souza CEV, Feres MAL, Petrelli E. Quem somos e como estamos em relação à Ortodontia contemporânea no Brasil: terceiro estudo. J Bras Ortodon Ortop Facial. 2003:8(47):401-18.

17. Vilella OV. O desenvolvimento da Ortodontia no Brasil. Rev Dental Press Ortod Ortop Facial. 2007;12(6):131-56. 